\title{
Partial purification and biochemical characterization of amylase from Aeromonas caviaeNK1isolated from Industrial waste of India
}

\author{
Kalyani Khanra \\ Department of Biotechnology, PanskuraBanamali College \\ Panskura RS; PIN 721152; PurbaMedinipur; West Bengal; INDIA \\ Indranil Choudhuri \\ Department of Biotechnology, Panskura Banamali College \\ Panskura RS; PIN 721152; Purba Medinipur; West Bengal; INDIA
}

\begin{abstract}
Sudipta Panja
${ }^{1}$ Department of Biotechnology, Panskura Banamali College

Panskura RS; PIN 721152; Purba Medinipur; West Bengal; INDIA
\end{abstract}

Nandan Bhattacharyya (Corresponding author)

Department of Biotechnology, Panskura Banamali College

Panskura RS; PIN 721152; Purba Medinipur; West Bengal; INDIA

Tel: 919-434-453-188_E-mail: bhattacharyya_nandan@rediffmail.com

Received: September 26, 2015 Accepted: October 18, 2015

doi:10.5296/jbls.v7i1.8361 URL: http://dx.doi.org/10.5296/jbls.v7i1.8361

\begin{abstract}
A partial purification and biochemical characterization of theamylase from AeromonascaviaeNK1 were carried out in this study. The extracellular extract was
\end{abstract}


concentrated using ammonium sulfate precipitation and optimum operational conditions for the enzyme activity from the strain were evaluated. The optimum $\mathrm{pH}$ and temperature were observed 11.5 and $37^{0} \mathrm{C}$ respectively. $\mathrm{Ca}^{2+}, \mathrm{Mn}^{2+}, \mathrm{Mg}^{2+}, \mathrm{Zn}^{2+}, \mathrm{Pb}^{2+}, \mathrm{Co}^{2+}$ were found to have effect on amylase activity.Furthermore, the analysis of kinetic showed that the enzyme has $K_{m}$ of $2.4 \mathrm{mg} / \mathrm{mL}$ and $V_{\max }$ of $21853.0 \mu \mathrm{mol} / \mathrm{min} / \mathrm{mg}$ for starch. The results indicate that the enzyme reflects their potentiality towards industrial utilization.

Keywords: Amylase, Partial purification, Km, V max, Zymogram

\section{Introduction}

The enzyme of amylase familyhas a great significance due to its wide area of potential application. Amylases can be of two types, endoamylases and exoamylases. Endoamylaseshydrolyzein a random manner in the interior of starch molecules and thus can produce linear and branched oligosaccharides of various chain lengths. On the other handexoamylaseshydrolyze the starch molecules from the non-reducing end successively which results in short end products (Reddy, Nimmagadda\& Rao, 2004).

Amylases catalyze the hydrolysis of alpha-1,4-glycosidic linkages of polysaccharides to yield dextrin, oligosaccharides and maltose. Mainly three types of amylases are found differing in the glycoside bond they attack- $\alpha, \beta$ and $\gamma$ amylases. Although they can be isolated from different source like animal, plant and microorganism, the microbial amylases are more thermostable and have higher yield(Burhan et al., 2003). The production of microbial amylases from bacteria is dependent on type of strain, composition of medium, method of cultivation, cell growth, nutrient requirements, metal ions, $\mathrm{pH}$, temperature, time of incubation and thermo-stability (Haq, Javed, Hameed \& Adan, 2004). Spectrum of application of amylase has widened in many sectors such as food, textile, baking and detergent industries. Besides its use in the saccharification or liquefaction of starch that converts starch into fructose and glucose, the enzyme is also used as a partial replacement for the expensive malt in the brewing industry to improve flour in the baking industry. They are used for the warp sizing of textile fibers, the clarification of haze formed in beer or fruit juices and for pre-treatment of animal feed to improve digestibility (Nusrat\& Rahman, 2008). Amylases have been derived from several fungi, yeast, bacteria and actinomycetes but members of the genus Bacillus are heterogeneous and they are very versatile in their adaptability to the environment.Amylases have been purified earlier from various Bacillus species such as Bacillusmegaterium(Oyeleke, Auta\&Egwim, 2010) from Bacillussubtilis (Riaz,Haq\&Qadeer, 2003), from Bacilluslicheniformis SPT 27 (Aiyer, 2004), from Bacillus licheniformis, Bacillus amyloliquifaciens (Vidyalakshmi, Paranthaman\&Indhumathi, 2009). Diverse fungal strains are able to produce amylase both intracellularly and extracellularly depending upon the fermentation process (Ellaiah,Adinarayana, Sunitha, \&Bhavani Devi, 2003; Vahidi, Shafagi\&Mirzabeigi, 2005; Chadha, Rubinder\&Saini, 2005).

In the present study we report partial purification and characterization of wide $\mathrm{pH}$ tolerant, $\alpha$-amylase produced by AeromonascaviaeNK1which was isolated from industrial waste of an industrial zone in West Bengal, India. 


\section{Materials and Metdods}

\subsection{Strain}

A new strain of AeromonascaviaeNK1 was identified from the industrial waste. The strain was maintained in the nutrient agar slant at $4^{0} \mathrm{C}$. The bacteria were revived by inoculating in $\mathrm{LB}(0.1 \% \mathrm{v} / \mathrm{v})$ and incubated at $37^{\circ} \mathrm{C}$ in a shaker incubator for overnight.

\subsection{Extraction and Partial Purification of Amylase Enzyme from the Isolated Bacteria}

The isolated bacteria were cultured in $100 \mathrm{ml}$ starch containing mineral medium for $30 \mathrm{~h}$ in shaker incubator at $120 \mathrm{rpm}$ and $37^{\circ} \mathrm{C}$. The extracellular enzyme was collected by centrifugation at $3000 \mathrm{Xg}$ for $20 \mathrm{~min}$ using cooling centrifuge (REMI C30 plus). The supernatant was collected as crude extract of enzyme. The enzyme was purified by ammonium sulphate precipitation up to $80 \%$ saturation. The precipitates were collected from different concentration of ammonium sulphate. Then the precipitates were re-suspended in 10 $\mathrm{ml}$ of $100 \mathrm{mM}$ Tris buffer of $\mathrm{pH} 10$ and dialyzed overnight.

\subsection{Protein Content Estimation}

For protein content estimation standardLowrey method of protein estimation was used (Lowry, Rosebrough, Farr \& Randall, 1951). Different dilutions from $0.2 \mathrm{mg} / \mathrm{ml}$ to $0.8 \mathrm{mg} / \mathrm{ml}$ of Bovine Serum Albumin (BSA) solutions were prepared by mixing of stock BSA solution $(1 \mathrm{mg} / \mathrm{ml})$ and distilled water in test tubes to final volume of $5 \mathrm{ml} .0 .2$ mlproteinsolutionsfrom each were pipetted in fresh test tubes and $2 \mathrm{ml}$ of alkaline copper sulphate reagent was added to each. The solutions were mixed well and incubated at room temperature for $10 \mathrm{~min} .0 .2 \mathrm{ml}$ of FolinCiocalteau solution was then added to each tube and incubated for $30 \mathrm{~min}$. The absorbance of each mixture was then measured using spectrophotometer (Bio Spectrometer, Eppendorf) at $600 \mathrm{~nm}$. The absorbance was plotted against protein concentration to get a standard calibration curve. The concentration of the unknown samples was determined from the plotted standard curve.

\subsection{Molecular weight determination of the purified amylase by SDS-PAGE}

The molecular weight of the partially purified amylase was determined by using SDS-PAGE as per description of Laemmli(Laemmli, 1970). The concentrations of staking gel and resolving gel in this experiment were $4.5 \%$ and $12.5 \%$ respectively. The purified amylase was loaded into the well parallel to standard protein marker. The protein band was detected by staining with $0.2 \%$ Coomassie brilliant Blue R250 and destining by methanol-acetic acid-water solution (4:1:5).

\subsection{Zymogram of Amylase Activity}

For determination of Zymogram, enzyme was subjected to native gel electrophoresis with the use of $10 \%$ acrylamide gel. $0.2 \%$ soluble starch was incorporated into the separating gel. After the electrophoresis, washing the gel at room temperature in solutions containing $50 \mathrm{mM}$ $\mathrm{Na}_{2} \mathrm{HPO}_{4}, 50 \mathrm{mM} \mathrm{NaH} \mathrm{PO}_{4}(\mathrm{pH} 7.2$ for $1 \mathrm{~h}$ for activity of enzyme.Gel was stained in a solution of iodine (Iodine $5 \mathrm{~g} / \mathrm{l}$, KI $50 \mathrm{~g} / \mathrm{l}$ ) (Lee,Morikawa, TakagiandImanakawa, 1994; Lin, 
Chyau and Hsu1998).

\subsection{Enzyme Assay}

Amylase activity was determined by measuring the release of reducing sugar from soluble starch. The reaction mixture contained $0.5 \mathrm{ml}$ of crude enzyme and $1 \mathrm{ml}$ of sodium phosphate buffer ( $\mathrm{pH} 7.0) .1 \%$ soluble starch was then added and incubated at $25^{\circ} \mathrm{C}$ for $10 \mathrm{~min}$. The amount of reducing sugar released in the mixture was determined by the addition of $2 \mathrm{ml}$ of 3,5-dinitrosalicylic acid (Miller, 1959) followed by boiling for $10 \mathrm{~min}$ to develop color. The absorbance of the mixture was measured at $540 \mathrm{~nm}$, and D-glucose was used to create a standard curve. One unit of enzyme activity was defined as the amount of enzyme releasing reducing sugar equivalent to $1 \mu \mathrm{mol}$ glucose per minute under the assay condition. The effect of temperature, $\mathrm{pH}$ and substrate concentration on amylase activity was studied and $\mathrm{Km}$ and Vmax values of the enzyme were calculated from Lineweaver-Burk (double-reciprocal) plot (Mishra \&Behera, 2008; Najafi, Deobagkar\&Deobagkar, 2005; Sudharhsan, Senthilkumar\&Ranjith, 2007).

\subsection{Optimization of Enzyme Activity}

Amylase activity was optimized in respect of $\mathrm{pH}$, temperature, substrate concentration and metal ions.

\subsubsection{Effect of $\mathrm{pH}$ for on the activity and stability of amylase}

Enzyme activity at the $\mathrm{pH}$ range from 4 to 12 were determined by 3,5-dinitrosalicylic acid reagent method as described earlier in 2.6.

\subsubsection{Effect of temperature on the activity and stability of amylase}

The enzyme activity (U) were measured by 3,5- dinitrosalicylic acid reagent at the temperature of $20^{\circ} \mathrm{C}, 30^{\circ} \mathrm{C}, 37^{\circ} \mathrm{C}, 40^{\circ} \mathrm{C}, 50^{\circ} \mathrm{C}$ at the optimum $\mathrm{pH}$, thatwas noted earlier, for the determination of activity and the stability of the enzyme.

\subsubsection{Effect of substrate concentration on the activity and stability of Amylase}

For the determination of the optimum substrate concentration,2, 4, 6, 8, $10 \mathrm{mg} / \mathrm{ml}$ of starch solutions were prepared. Amylase activity was measured at varying concentrations of starch under optimal conditions on the basis of the information obtained in previous experiment (optimum $\mathrm{pH}$, optimum temperature).

2.7.4 Effect of cations and heavy metal ions on the activity and stability amylase

The effect of cations on enzyme activity was studies by using Calcium (0.4-2.5 mM), Magnesium (1-7 mM), Manganese (0.4-2.8 mM), and Zinc (0.1-1mM) ions. They have positive effect on amylase production. We used Lead $(0.1-1 \mathrm{mM})$ and Cobalt $(0.1-1 \mathrm{mM})$ to study the effect of heavy metal ions on enzyme activity. 


\section{Macrothink}

\section{Results and Discussions}

\subsection{Molecular Weight of the Purified Amylase}

The molecular weight of the purified amylase on the basis of SDS-PAGE is $\sim 55 \mathrm{kDa}$ as shown in Figure 1. The figure shows that the amylase is partially purified.

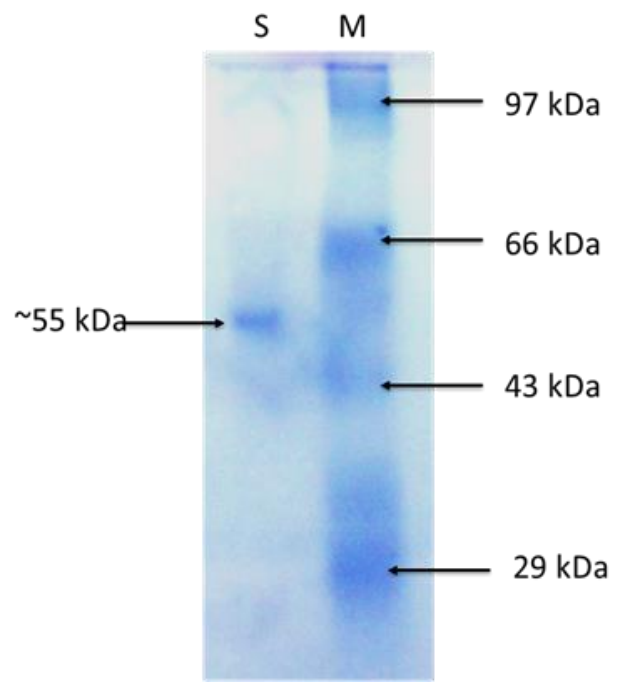

Figure 1. Molecular weight of the crude enzyme determined by SDS-PAGE. S stands for partially purified sample, M stands for molecular weight marker

\subsection{Zymogram}

The enzyme activity was observed in native PAGE gel containing $0.2 \%$ agar. A hallow zone of digested starch was detected in gelindicating activity of amylase enzyme (Figure 2).

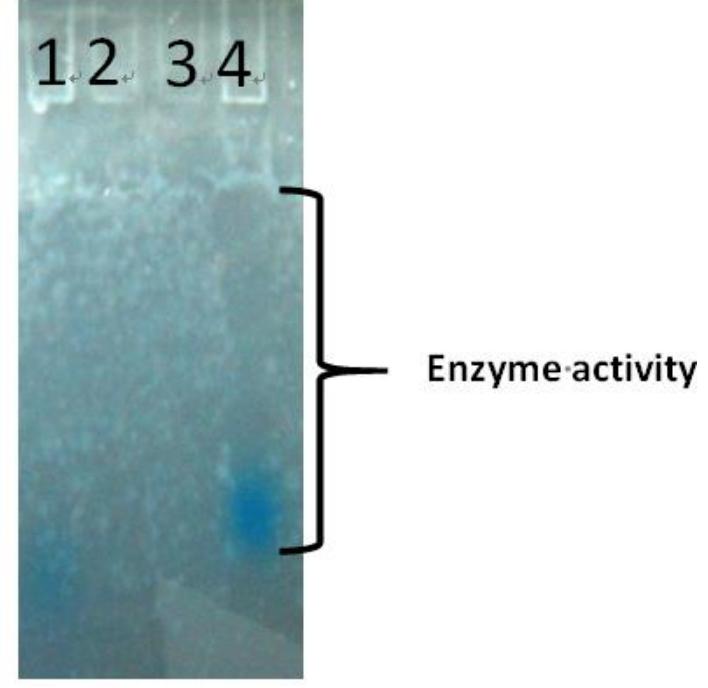

Figure 2. Zymogram of amylase activity. Proteins were loaded in Lane $1 \& 4 . \quad$ Lanes 2 and

3 were empty lanes. $20 \mu \mathrm{g}$ of BSA was loaded in lane 1 and $20 \mu \mathrm{g}$ of partially purified amylase was loaded in Lane 4. Amylase breakdown the starch and clear zone is appeared in

\section{Lane 4}




\section{Macrothink}

\subsection{Enzyme Kinetics}

The partially purified $\alpha$-amylase enzyme was incubated with various concentrations $(0.5-8.0 \mathrm{mg} / \mathrm{mL})$ and time of soluble potato starch under $37{ }^{0} \mathrm{C}$ temperature and $\mathrm{pH} 7$ to determine the kinetic parameter (Roy et al., 2014). The Michaelis-Menten constant $(\mathrm{Km})$ and maximum velocity $(V \max )$ values were determined from Lineweaver-Burk plots. The $\mathrm{Km}$ and $V \max$ values were calculated from the kinetic data. The enzyme has $K_{m}$ of $2.4 \mathrm{mg} / \mathrm{mL}$ and $V_{\max }$ of $21853.0 \mu \mathrm{mol} / \mathrm{min} / \mathrm{mg}$ for starch (Figure 3).

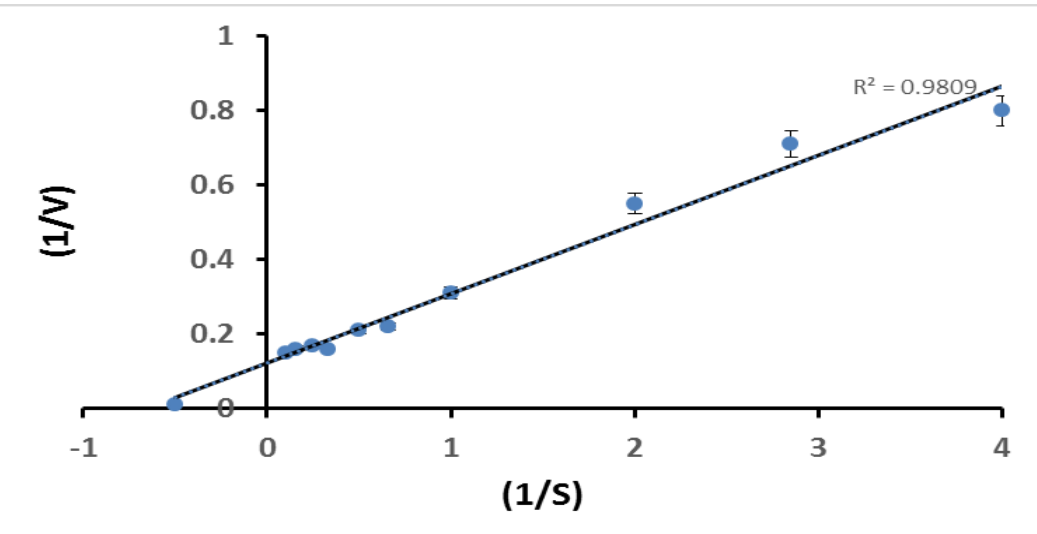

Figure 3. Lineweaver-Burk plot for $K m$ and $V \max$ values of the $\alpha$-amylase in the presence of different concentrations of soluble starch.

\subsection{Optimum Condition and Stability of the Enzyme}

The enzyme showed $100 \%$ activity at $\mathrm{pH} 11.5$ in Figure $4 \mathrm{a}$ and temperature $37^{\circ} \mathrm{C}$ in Figure $4 \mathrm{~b}$. The enzyme is also $70 \%$ to $100 \%$ active at the $\mathrm{pH}$ range from 7 to 12 and temperature $20^{\circ} \mathrm{C}$ to $40^{\circ} \mathrm{C}$. It was also noted that with increasing the substrate concentration up to 1 $\mathrm{mg} / \mathrm{ml}$ the activity of the enzyme increases and showed $100 \%$ efficiency. With respected to the further increase in substrate concentration there is no change in the enzyme activity. The enzyme showed wide range of $\mathrm{pH}$ activity. It may eliminate the requirement of $\mathrm{pH}$ adjustment in its industrial application which is an important factor for its industrial application.

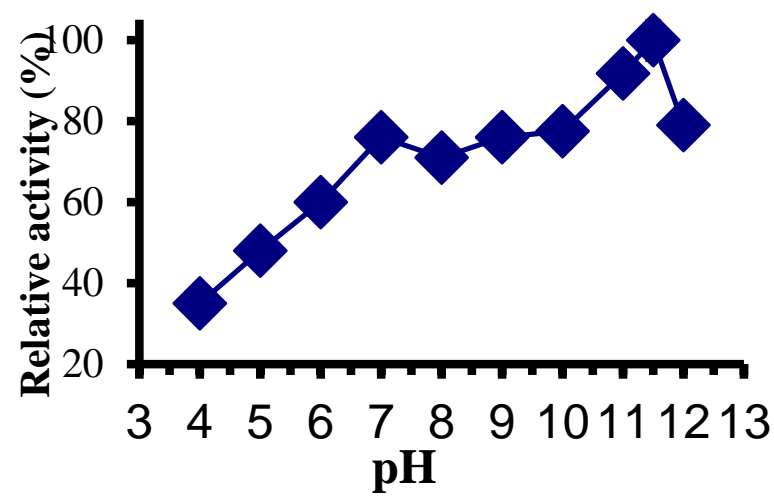

Figure 4a. Effect of $\mathrm{pH}$ on the activity of purified enzyme 


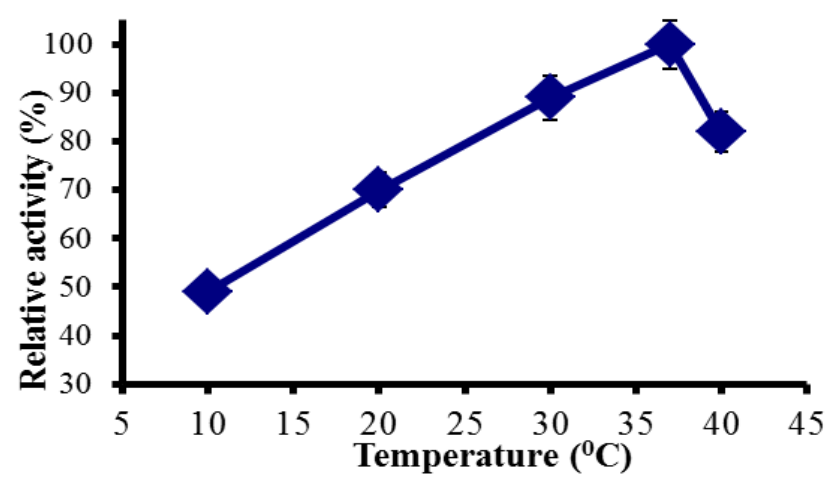

Figure 4b. Effect of Temperature on the activity of purified enzyme

\subsection{Effect of Cationsand Heavy Metal Ions on Amylase Production}

The data of effect of ions on enzyme activity indicate that the relative activity is $100 \%$ in presence of $0.8 \mathrm{mM}, 1.5 \mathrm{mM}, 0.75 \mathrm{mM}, 5 \mathrm{mMof} \mathrm{ZnCl}_{2}$, calcium chloride, Manganese chloride, Magnesium chloride, and respectively (Fig 5 A, B,C, D). So calcium chloride and magnesium sulfate stimulated the amylase activity. On the other hand, in presence of leadion, cobalt ions ( $4 \mathrm{mM}$ and $0.1 \mathrm{mM}$ respectively), relative activity of enzyme is $100 \%$ (Fig $5 \mathrm{E}, \mathrm{F}$ ). Then after increasing of cobalt ion the activity gradually decreased. So cobalt ion has an inhibitory effect of heavy metal on amylase activity.
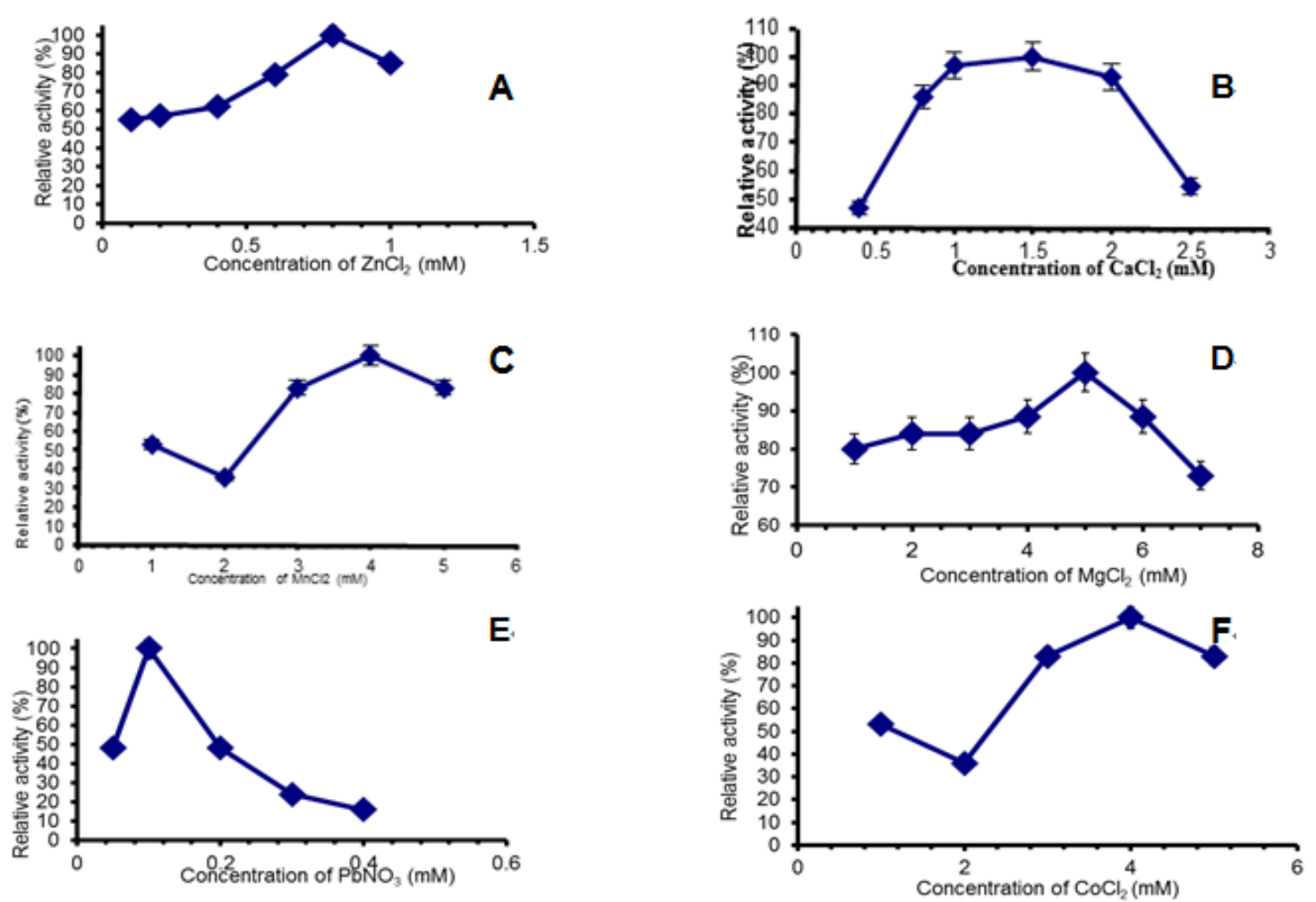

Figure 5. Effect of cations and heavy metals on the activity of purified enzyme 


\section{Conclusion}

Current results indicate that the $\sim 55 \mathrm{kDa}$ amylase enzyme is active at wide range of $\mathrm{pH}$ and temperature. This study also revealed that amylolytic activity was affected by cation like calcium and magnesium concentration. In presence of calcium and magnesium ion in a specific range the enzyme activity increased. Lead $(\mathrm{Pb})$ ion has an inhibitory effect of heavy metal on amylase activity.

\section{References}

Aiyer, P. D. (2005). Effect of C: N ratio on alpha amylase production by Bacillus licheniformis SPT 27. African Journal of Biotechnology, 3(10), 519-522.

Burhan, A., Nisa, U., Gökhan, C., Ömer, C., Ashabil, A., \& Osman, G. (2003). Enzymatic properties of a novel thermostable, thermophilic, alkaline and chelator resistant amylase from an alkaliphilic Bacillus sp. isolate ANT-6. Process Biochemistry, 38(10), 1397-1403. http://dx.doi.org/10.1016/S0032-9592(03)00037-2

Chadha, B. S., Rubinder, K., \& Saini, H. S. (2005). Constitutive $\alpha$-amylase producing mutant and recombinant haploid strains of thermophilic fungusThermomyceslanuginosus. Folia microbiologica, 50(2), 133-140. http://dx.doi.org/10.1007/BF02931462

Ellaiah, P., Adinarayana, K., Sunitha, M., \&Bhavani Devi, R. (2003). Isolation of $\alpha$-amylase producing fungi from some soils in India. Indian Journal of Microbiology, 43(2), 135-137.

Haq, I., Javed, M. M., Hameed,U.,\& Adnan, F. (2010).Kinetics and thermodynamic studies of alpha amylase from Bacillus lichenoformis mutant. Pak. J. Bot, 42(5), 3507-3516.

Laemmli, U. K. (1970). Cleavage of structural proteins during the assembly of the head of bacteriophage T4. nature, 227(5259), 680-685.

Lee, S., Morikawa, M., Takagi, M. \&Imanakawa, T.(1994). Cloning aapT Gene and Characterization of its product, a-amylase, pullulanase (aapT), from Thermophilic and alkaliphilic Bacillus sp. Strain XAL601. Applied Environmental Microbiology 60, 3761-3773.

Lin, L. L., Chyau, C. C., \& Hsu, W. H. (1998). Production and properties of a raw-starch-degrading amylase from the thermophilic and alkaliphilic Bacillus sp. TS-23. Biotechnology and Applied Biochemistry, 28(1), 61-68.

Lowry, O. H., Rosebrough, N. J., Farr, A. L., \& Randall, R. J. (1951). Protein measurement with the Folin phenol reagent. J biolChem, 193(1), 265-275.

Miller, G. L. (1959). Use of dinitrosalicylic acid reagent for determination of reducing sugar. Analytical chemistry, 31(3), 426-428. http://dx.doi.org/10.1021/ac60147a030

Mishra, S., \&Behera, N. (2008). Amylase activity of a starch degrading bacteria isolated from soil receiving kitchen wastes. African Journal of Biotechnology, 7(18), 3326-3331.

Najafi, M. F., Deobagkar, D., \&Deobagkar, D. (2005). Purification and characterization of an extracellular $\alpha$-amylase from Bacillus subtilis AX20. Protein expression and purification, 
41(2), 349-354. http://dx.doi.org/10.1016/j.pep.2005.02.015

Nusrat, A., \& Rahman, S. (2010). Partial Characterization of Extracellular \&alpha-Amylase from Three Bacillus Isolates. Bangla. J. Microbiol., 25(1). http://dx.doi.org/10.3329/bjm.v25i1.4864

Oyeleke, S. B., Auta, S. H., \&Egwim, E. C. (2010). Production and characterization of amylase produced by Bacillus megaterium isolated from a local yam peel dumpsite in Minna, Niger State. Journal of Microbiology and Antimicrobials, 2(7), 88-92.

Reddy, N. S., Nimmagadda, A., \& Rao, K. S. (2004). An overview of the microbial $\alpha$-amylase family. African Journal of Biotechnology, 2(12), 645-648.

Riaz, N., Haq, I., \&Qadeer, M. A. (2003). Characterization of $\alpha$-amylase by Bacillus subtilis. Int J AgrBiol, 5(3), 249-252.

Roy, A., Khanra, K., Mishra, A., \& Bhattacharyya, N. (2014). Partial purification and characterization of amylase from a newly isolated Bacillus megaterium Strain KAN1 from fermented rice Handia. American Journal of Current Microbiology, 2(1), 1-5.

Sudharhsan, S., Senthilkumar, S., \&Ranjith, K. (2007). Physical and nutritional factors affecting the production of amylase from species of bacillus isolated from spoiled food waste. African Journal of Biotechnology, 6(4), 430-435.

Vahidi, H., Shafagi, B., \& Mirzabeigi, Z. (2005). Culture medium optimization of?-amylase producing organism Mocur spp. using the variable size-simplex algorithm. DARU Journal of Pharmaceutical Sciences, 13(1), 20-22.

Vidyalakshmi, R., Paranthaman, R., \& Indhumathi, J. (2009). Amylase production on submerged fermentation by Bacillus spp.World Journal of Chemistry, 4(1), 89-91.

\section{Copyright Disclaimer}

Copyright for this article is retained by the author(s), with first publication rights granted to the journal.

This is an open-access article distributed under the terms and conditions of the Creative Commons Attribution license (http://creativecommons.org/licenses/by/3.0/). 